\title{
Influence of Forest Roads, Distance from the Boundary and Location of Sites on Illegal Activities in Arabuko Sokoke Forest, Coast-Kenya
}

\author{
Mwendwa A. Kaleb ${ }^{1, ~ *, ~ A g e v i ~ H u m p h r e y ~}{ }^{2}$ \\ ${ }^{1}$ Science and Math Education Department \& Centre for Kakamega Tropical Forest Studies (CEKATFOS), Masinde Muliro University of \\ Science and Technology, Kakamega, Kenya \\ ${ }^{2}$ Biological Sciences Department \& Centre for Kakamega Tropical Forest Studies (CEKATFOS), Masinde Muliro University of Science and \\ Technology, Kakamega, Kenya
}

\section{Email address:}

kmwendwa@mmust.ac.ke (K. A. Mwendwa),kalebmwendwa@gmail.com (K. A. Mwendwa), hagevi@mmust.ac.ke (A. Humphrey), agevihum@yahoo.com (A. Humphrey)

${ }^{*}$ Corresponding author

\section{To cite this article:}

Mwendwa A. Kaleb, Agevi Humphrey. Influence of Forest Roads, Distance from the Boundary and Location of Sites on Illegal Activities in Arabuko Sokoke Forest, Coast-Kenya. American Journal of Agriculture and Forestry. Vol. 8, No. 6, 2020, pp. 235-246. doi: 10.11648/j.ajaf.20200806.11

Received: February 21, 2017; Accepted: October 28, 2020; Published: October 30, 2020

\begin{abstract}
Forest roads play an important role in the management of forests. There is a high dependency on natural forests and its products by the forest adjacent communities (FACs) in the tropics. Protection is a key element in controlling the illegal activities in these forests and road networks within and around them play an important role. Arabuko Sokoke forest (ASF) in the Coast of Kenya has been under threat from the illegal activities. A study was carried out to assess the influence of forest roads, distance from the boundary, and relative location of sites on the illegal activities of the Arabuko Sokoke forest. Four (4) Road classes (20c, 40c, 50c, and 75c.-with 20c being the poorest in that order), 3 distances from the boundary (DFB $-1 \mathrm{~km}$, $2 \mathrm{~km}$ and $3 \mathrm{~km}$ ) and 10 sites (Dida, Jilore, Kaembeni, Malanga, Matsangoni, Mida /Arabuko, Mwambani Nature Reserve, Pahalipeupe and Sokoke) were the main factors assessed relative to the number of stumps, traps, herbs collection, paths, stacks and debarking incidences. DFB, road class and site interactions were highly significant $(p<0.05)$ on the number of stumps, traps and paths found in the forest. Dida $>$ Kaembeni $>$ Mwambani sites had the most illegal incidences compared to the others. In several areas, DFB of $3 \mathrm{~km}$ and $20 \mathrm{c}$ and $40 \mathrm{c}$ road-classes were interactions were found to be highly significant $(\mathrm{p}<0.05)$. The study showed that poorer roads classes in the Arabuko Sokoke forest is encouraging the illegal activities. The poorer the road classes the higher the occurrence of the illegal activities. There is a need to reassess the road network with a view of increasing efficiency of patrol. The number of patrolmen and vehicles need to be increased. The vehicles should be equipped with a geographic positioning system (GPS) tools to increase monitoring of the activities and enhance the planning of patrol programmes. Surrounding populations and historical factors were found to be important in those three areas.
\end{abstract}

Keywords: Forest Roads, Sites, Stumps, Traps, Debarking, Stacks, Road Classes, DFB

\section{Introduction}

Forest communication especially forest roads are necessary for the management of the forests. Forest roads are the basis for connection among other means of communication within a forest [1]. Better roads lead to a higher standard of living. This slogan illustrates the national economic aspect on roads in general, but it also applies to the forestry, with better road conditions, a prerequisite for intensive forest management. The main use of the forest roads is to make the harvesting of the raw materials possible. Due to the exploitation principle, which commonly characterizes the operations, the roads are intended for use only during the harvesting phase. Later after logging has covered the whole area, the roads are abandoned. Roads are always a prerequisite for forest management, regardless of the level of management. The number of roads in 
an area, their spacing and density may largely differ according to the case inspection, patrolling or other visits for planning purposes that are frequently required when practicing intensive management [2]. The better access the manager or his staff has to an area the more effective the management can be assumed to be and actions are taken in due course when needed. It is easy to deploy labour to carry out the wanted operations if the road conditions are good. Roads are important for e.g. fire control, as a boundary to ground fires and movement of equipment. Probably the most important reason for high quality roads in an area is that the whole area is accessible throughout the entire year for practicing forest management. Increased focus should be placed on environment and human protection questions $[3,4]$. Therefore, it is possible to build a permanent and ongoing system based on the use of resources. Any type of operation can be carried out anywhere at any time without much problem of accessibility. Forest roads may be tarmacked, gravelled or metalled (using hard core) and often have restrictions on use. In many regions, the establishment of forest roads is not only subject to approval under forest management law, but also conservation law. In riparian forest and other especially important conservation areas, forest roads and tracks are generally signed as being bounds and/or closed off with barriers [5]. Forest roads are also a significant contributor to water conservation and biodiversity [6]. Arabuko Sokoke forest is the largest existing block of forest that is remaining along the Kenyan coast. This forest has many endemic and endangered species that include wild animals, birds and plants. It consists of three major vegetation types namely the Cynometra, the Brachystegia and the mixed forest which used to be called the Afzelia forest. These three areas are utilized differently by the communities around the forest. The Mixed forest has got a higher biodiversity as compared to the other areas in terms of timber species followed by the Cynometra and the Brachystegia respectively. In the recent past the local urban areas' development and population increase has led to a higher demand for forest products for the building tourist hotels and for the local community construction. Forest products utilization from indigenous forests is currently only limited to dead fuelwood collection and non-timber products like honey. The Kenya Forest Service (KFS) and Kenya Wildlife Service (KWS) are faced with labour shortage with most of the forest guards and rangers going on early retirement or retrenched thus affecting patrolling activities in the forest $[7,15])$. The number of the forest guards and Kenya Wildlife Service rangers in the Arabuko Sokoke forest currently stands at about 23 forest guards and about 20 rangers in the Kilifi county. They are supposed to cover the entire $41765 \mathrm{Ha}$ of the forest. This means that one forest guard/ranger is supposed to cover an area $1816 \mathrm{Ha}$. For effective patrolling, thus it requires vehicle and foot patrolling. In order to know the amount of the forest roads that are sufficient for the control of the illegal activities in the forest, a study was conducted to determine the effect of the already existing road pattern in the forest and its effects on the illegal activities. This was to determine whether better roads open up the forest and increases poaching or they lead to better patrolling and reduce poaching. This study is vital in the management of the Arabuko Sokoke forest as it will help in making the long-term decisions on the protection of the forest. This is the first time a scientific based system is being applied to the issue of forest roads in Natural Forests in Kenya and possibly elsewhere as regards illegal activities vis-à-vis utilization.

\section{Materials and Methods}

\subsection{Materials and Methods Used in the Study}

These were supplemented by information obtained through GIS applications.

\subsubsection{Study Area}

Arabuko Sokoke Forest reserve is the last remaining tracts of lowland forest in Kenya. The forest reserve is in Kilifi County of the Coast Kenya. It lies between 10 to $25 \mathrm{~m}$ above sea level and covers an area of approximately $41000 \mathrm{Ha}$ or $400 \mathrm{~km}^{2}$. The Arabuko Sokoke forest is the largest extant stand of continuous forest cover on the Eastern African coast. It lies close to the Indian Ocean in Kilifi and Malindi districts of coast province about $75 \mathrm{~km}$ from Mombasa. The forest covers $41765 \mathrm{Ha}$ (Figure 1). The eastern boundary stretches along the main Kilifi-Malindi road starting $12 \mathrm{~km}$ north of Kilifi town and continuing for about $20 \mathrm{~km}$. The Kilifi-Dida road runs through the southwestern corner of the forest while the Sabaki River flows along the northern boundary. There are numerous access and old logging tracks running into the forest from Kilifi-Malindi road, the Kilifi-Dida road and the roads along the western boundary. In addition, there is a major track running through the forest from the Jilore forest station to the Malindi-Kilifi road close to the Gee forest station. Overall it is relatively easy for motor vehicles to enter and depart from the forest [7].

\subsubsection{Vegetation Distribution}

Arabuko Sokoke Forest is the largest remnant of the North Coast forest, which once dominated Kenya's coastal fringe. Surveys including those done by Kenyan Indigenous Forests Conservation (KIFCON) project have confirmed the importance of Arabuko Sokoke as a habitat for several endemic /endangered bird and mammals' species. There are four distinct Vegetation types in Arabuko Sokoke forest (Figures 1 \& 3). These are:

Table 1. Area covered by the different vegetation types in ASF.

\begin{tabular}{ll}
\hline Vegetation & Area (Ha) \\
\hline Cynometra /thicket & 26,785 \\
Brachystegia woodland & 7,630 \\
Mixed forest & 6,565 \\
Non-indigenous plantations. & 777 \\
Total & 41,757 \\
\hline
\end{tabular}

Arabuko Sokoke Forest Management Team (2010).

Arabuko Sokoke is broadly divided into three vegetation types (Tab, dominated by the three species Brachystegia 
spiciformis, Cynometra webberi and the mixed species stands, which used to be dominated by Afzelia quanzensis [8],[9]. The variation in the vegetation types is a consequence of the soil types and the rainfall pattern [10]. The mixed forest forest is described as mixed semi-deciduous forest [9], and includes an area close to Gede Forest Station which some workers have inaccurately portrayed as lowland rainforest [8]. Dominant tree species include Afzelia quanzensis, Combretum schumanii Drypetes reticulata, Hymenea verrucosa, Dialium orientale, and Manikara sasibarensis, and less common species include Adansonia digitata (baobab) and Pleustrylia africana. The cycad Encephalartos hildebrandtii occurs throughout the mixed forest, more commonly than it does in the other areas [7]. Covering a similar area to the mixed forest, the Brachystegia forest stands on the drier white sand areas of the forest reserve. The hardwood Brachystegia spiciformis is dominant to the exclusion of almost all other tree species in some areas [11]. Growing alongside are Cassipourea euryoides, Afzelia quanzensis and Hymenea verrucosa. The local Giriama local name for this area, Sosoni, refers to white soil and lighter shade. Brachystegia regeneration is poor in some regions, maybe as a result of the fire changing regimes [12] and is thought to be a fire climax vegetation type (Glyn Davies Per. Comm). Such monospecific domination may be a consequence of severe nutrient leaching in the central thin white soil areas, where overall floral diversity is low [7]. Dominating over $65 \%$ of the forest, the Cynometra forest and thicket is confined to the so-called red soil, the belt that is furthest inland.

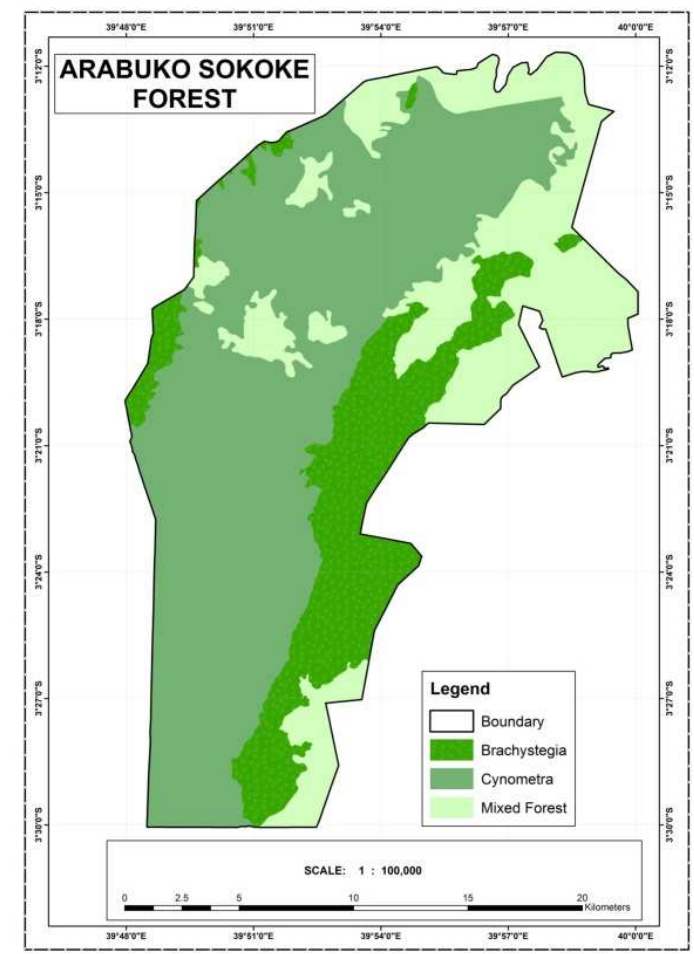

Figure 1. Arabuko Sokoke Map showing its geographical position and dominant vegetation types.

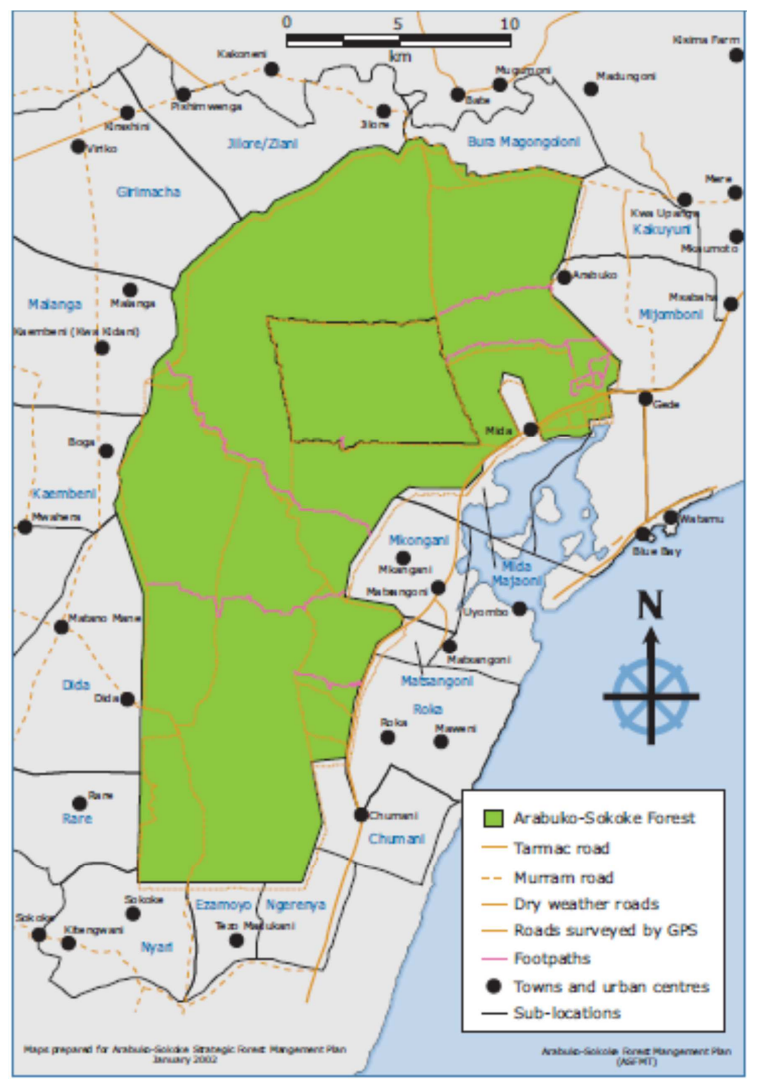

Figure 2. Administrative features of ASF.

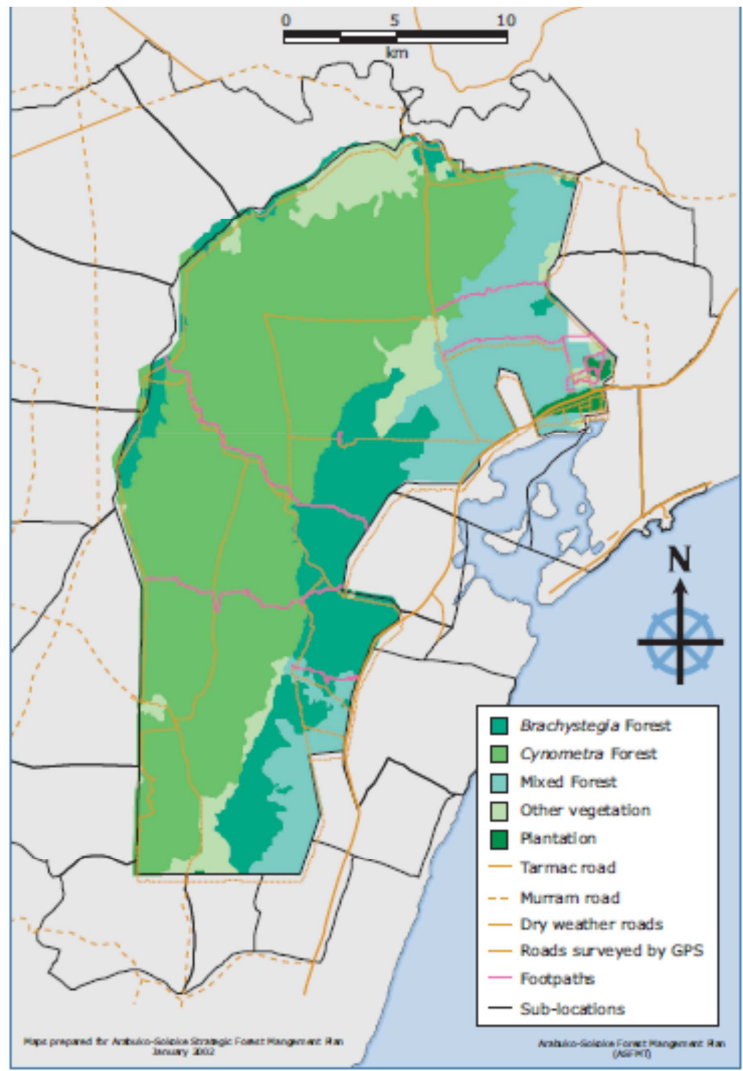

Figure 3. Vegetation types and road network within ASF. 


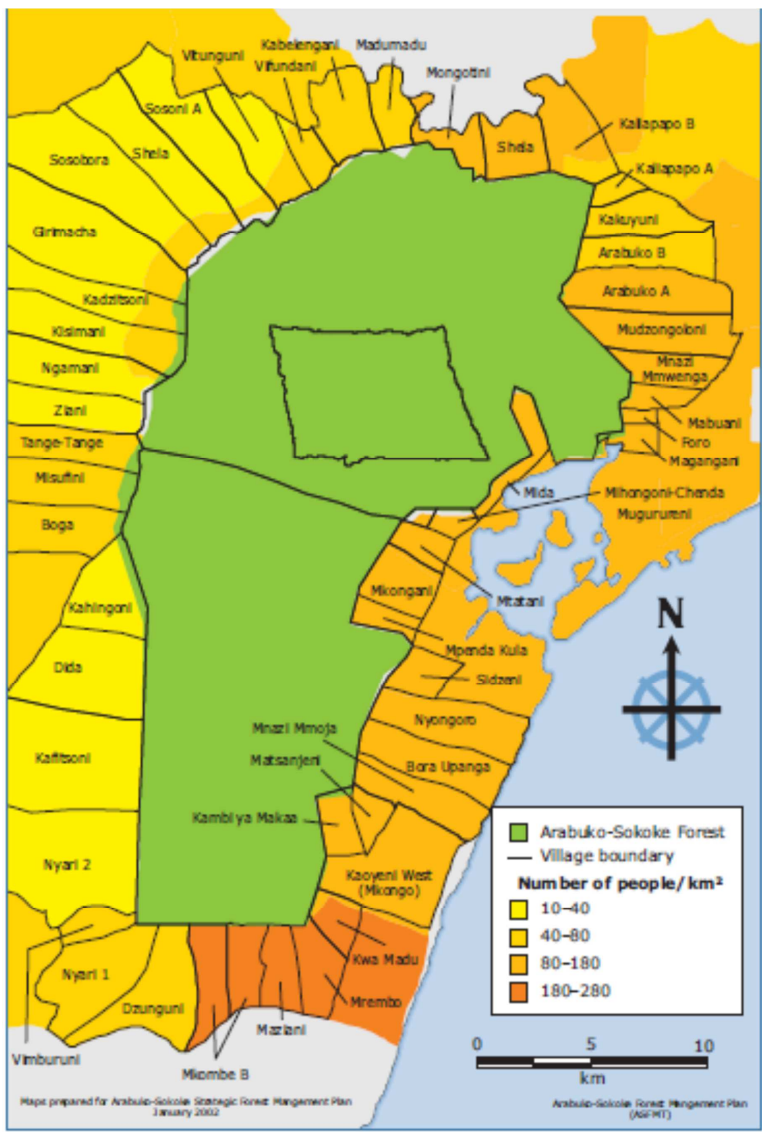

Figure 4. Population densities around ASF Villages.

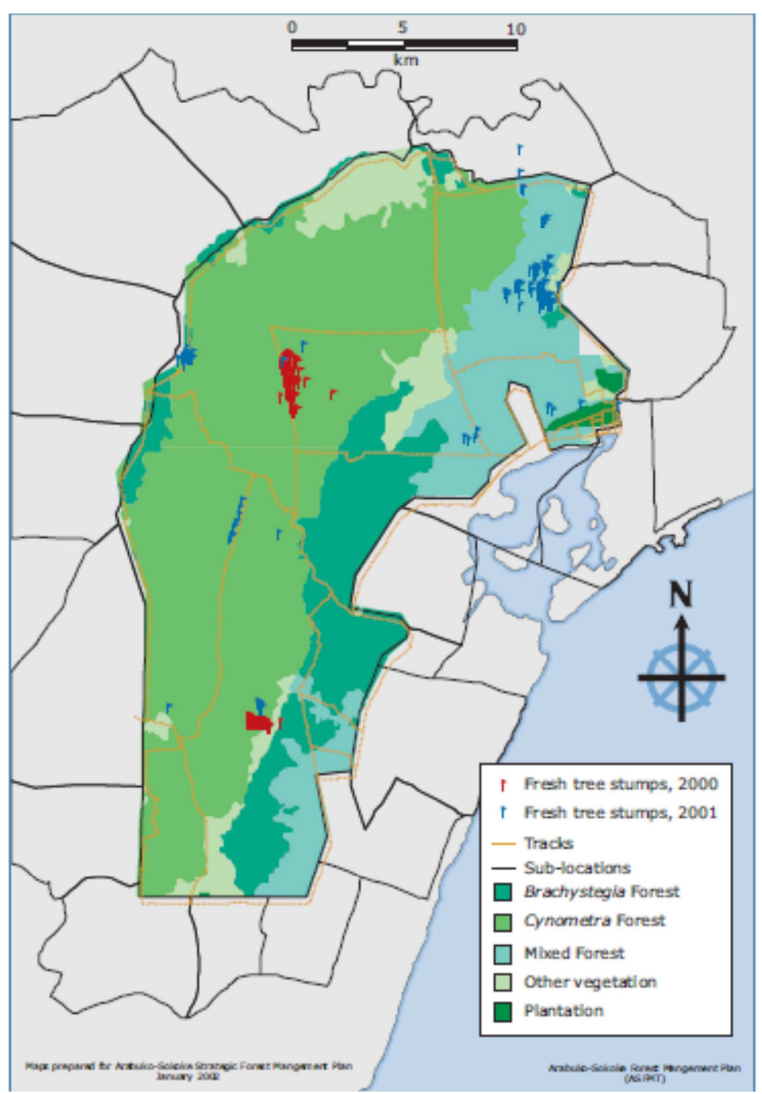

Figure 5. Illegal wood cutting in the years 2000 and 2001.
The local Giriama name Sokoke is the antonym of Sosoni, meaning thicket and dense shade (Arabuko is Sanya word for elephant) and this area is the thickest of the three with the closest tall trees and highest stem density. Dominant trees are Cynometra webberi, Manilkara sulcata, Oldfieldia somalensis and Brachylaena huillensis. In restricted areas of the Cynometra in the Southwest, Newtonia paciujuga and Aristogeitonia monophylla are found. The Cynometra and Brachystegia areas are separated by a low ridge and a series of pools, seasonal in occurrence, which are used as a source of water by both the small number of elephants in Sokoke and by the people from the surrounding villages like Matsangoni.

\subsubsection{Management}

By 1960, Sokoke covered an area twice as large as it does today. Within this extensive forest, $39,105 \mathrm{Ha}$ had been set aside as crown land in 1932 followed, in 1943 by gazettement as a forest reserve managed by the Forest Department [11]. Another 2,676 Ha were added at Kararacha and a strict nature reserve of $2,700 \mathrm{Ha}$ was gazzetted and expanded with to a further $1,635 \mathrm{Ha}$ in 1979 [11]. Outside the forest boundary, settlement since the 1980s has seen virtually all remaining vestiges of forest cover cleared for agriculture [13]. Management of the Arabuko Sokoke is undertaken from the forest offices at Gede, Jilore and Sokoke forest stations with a series of outposts at Kakayuni, Malanga, Kaembeni, Dida, Kararacha, Matsangoni and Mwambani. A memorandum of understanding signed in 1991 is already in place to allow the Kenya Forest Service (KFS) and the Kenya Wildlife Service to jointly manage the forest.

\subsubsection{Topography, Soils and Climate}

Arabuko Sokoke stands on flat coastal plain at sea level, rising to about $60 \mathrm{~m}$ along a low escarpment which cuts the forest from south-west to north east [9, 11]. An abrupt change in soil type, from light white sandy soils on the east to heavy red so called margarini sands which stretch inwards towards Tsavo East National Park is associated with this low escarpment [10]. The forest lies in a rainfall belt which receives between $900 \mathrm{~mm}$ and $1100 \mathrm{~mm}$ per annum [11]. The north-west that contains Cynometra forest, is the driest area of the Sokoke while the wettest is the mixed forest close to Gede forest station [10]. Annual rainfall is dominated by a long rainy season from April to June and short rains which usually fall from October to December. Daytime temperature range over $23^{\circ} \mathrm{C}-30^{\circ} \mathrm{C}$ in the Tana delta to the north and humidity is high all year round, at around $60 \%$ [11] while wind speed data for Malindi varies from 4-6 knots in the morning to 5-6 knots in the evening. There are two main soil types: a). Red loam sands: These types of soils are derived from tertiary sediments on higher ground to the north east of Sokoke, Dida, Jilore, Mida Kararacha, Nature Reserve and Arabuko. The common tree species here are the Cynometra webberi, Manilkara sulcata and Brachylaena huillensis b). Deep loose white sands: this type of soil is found on the lower ground at Gede and Kakuyuni, with the dominant species being, Afzelia species, Trachylobium verrucossum 
and Manilkara species.

\subsubsection{History and Utilization}

The area around Arabuko Sokoke forest reserve has been surrounded by human population for many years (see Figure 4 and Table 1). The increasing demand for cleared land for settlement and cultivation has progressively reduced the extent of the forest. Out of the area of the forest existing in the 1960 s only $50 \%$ had remained by 1971 [14]. Swedish and European timber merchants invaded the forest in the early 1900 s and removed most of the commercially valuable timber species. This activity attracted people in to the forest to look for employment. While the Sanya people were being threatened, the villages around Gede and Kakuyuni could have acted as central places for initial settlement. In the years of 1950s, settlements at Mijiomboni, Mahaji, Penda kula and Ngerenya expanded on the eastern border of the forest resulting in an increased impact upon the forest resource. The populations occupying these settlement schemes have had an increased level of traditional forest uses such as building and firewood collection. The western part however, has very low number of settlers. This has been attributed by lack of water but shifting cultivation has been practiced more on this side leading to the removal of most of the original vegetation outside the forest [15]. Arabuko Sokoke Forest reserve supplied boat and other building materials to the Arab traders. Sawmills established in the early 1900s mainly processed the following tree species of hardwoods: Sterculia appendiculata, Manilkara sansibarensis, Afzelia quanzensis

Table 2. Legal Status of Arabuko Sokoke Forest and changes in boundary.

\begin{tabular}{|c|c|c|c|c|}
\hline Details & Year & Boundary Plan & Legal Notice & Area per ha \\
\hline Original Gazettement & 1932 & $75 / 12$ & 44 & 39,089 \\
\hline Revocation of proclamation 44 and re-gazettement with new boundaries & 1943 & $175 / 44$ & 48 & 39,089 \\
\hline Declared Central forest & 1964 & & 174 & 39,089 \\
\hline Kararacha Extension & 1968 & $175 / 88$ & 149 & 2,675 \\
\hline Declaration of Nature Reserve (within forest reserve) & 1977 & $175 / 194$ & 100 & 2,699 \\
\hline Declaration of Nature reserve extension (within forest reserve) & 1979 & $175 / 215$ & 180 & 1,635 \\
\hline Declaration of National park (external to forest reserve & 1990 & & 426 & 600 \\
\hline
\end{tabular}

Source: Arabuko Sokoke Forest Strategic Management Plan (2002-2027)\& Arabuko Sokoke Forest Management Team (2002).

\subsection{Description of the Study and Illegal Activities}

This study investigated the influence the forest roads on the different illegal activities inside the Arabuko Sokoke forest. This was done by sub-dividing the whole forest into zones so as to capture the site factor. The illegal activities that were studied include the following: Stumps, Traps, Herbal medicine collection, Stacks, Paths, Debarked trees. These are some of the illegal activities that are commonly found in most of our Kenyan natural forests and looking at these could assist in tackling the problem of illegal activities in most of our Kenyan natural forests with the similar conditions like Arabuko Sokoke.

Stumps are as a result of the illegal felling of trees inside the forest by Poachers. They often target valuable hardwoods that fetch more money in the market as timber and/or carving wood. This illegal felling of trees changes the forest biodiversity and also interferes with its general health and and Brachyleana huillensis. Due to scarcity and also due to the local concern over the status of the forest, the sawmills had to close down. None the less owing to the establishment of Malindi and Kilifi and other urban centre the demand for building materials and the souvenir carving trade has increased which has depleted the forest resource. Hence due to the deteriorating status of the forest, the government took the step of gazzetting it in the year 1943. This was designed to manage and control the exploitation of the forest resource. They traditionally hunted for a living and their main target animals were the elephant and buffaloes. Others included antelopes, wild pigs and other lesser mammals [15] with the to obtain meat for consumption and the skins and tusks for sale to the Arabs at Malindi. Forest was a good source of wild honey and fruits, which the Sanya survived on. Sand was also another resource that used to be extracted from the large pits positioned towards the center of the remaining Mida -Gede rain forest. Charcoal extraction was also a common practice upto about 1976. There was not much control over the amount of timber exploitation in the forest reserve in the seventies. However, as a result of significant changes in forestry policy concerning the general approach to forestry in and around the reserve in 1978, the former policy of clear felling the indigenous forests and then replanting with fast growing exotic species was replaced. Actual restriction on the cutting of indigenous forest was not implemented until a presidential decree was passed in 1982 [8]. 
problem for Ader's duiker and the Sokoke bushy-tailed mongoose [18]. The other illegal activity (although not essentially illegal if it is for domestic purposes) is that of the rate of the herbal medicine collection in the forest. This is an activity which occurs in the forest when people around the forest collect the herbs for medicinal purposes or for any other purpose without permission from the necessary authorities. Stacks refers to the number of stacked firewood, withes, poles and timber. These are referred as illegal activities in the Arabuko Sokoke forest because there is no permission for anybody to collect any form of the forest product from the forest. This may be caused by the lack of alternative source of fuel-wood and building poles domestic and commercial use. Paths refers to the number of paths that inter-crossed each other in a given area. This parameter was included in the study also to show which part of the forest is mostly used. This was also aimed at identifying where the highest numbers of paths exist and whether this is where we have the roads or it is where we don't have the roads. A good number of the paths, it is thought have been created by the illegal poachers. Number of debarked trees, are the number of the trees which, their barks have been removed through deliberate action by individuals who have an aim of using the bark for several purposes. Generally, this is done with the following aims: To get barks to cover the beehives, to get barks to be used as medicine, to get barks to use as ropes to carry firewood, to get barks to use as ropes for setting animal traps and to damage the trees deliberately eventually causing premature death.

\subsection{Research Design}

This study was carried out in the Arabuko Sokoke forest where the forest was divided into regions to cater for the sitespecific factors. The forest was divided into the following ten regions: Mida \& Arabuko, Jilore, Nature reserve,
Matsangoni, Mwambani, Sokoke, Dida, Kaembeni, Malanga, Pahali peupe. The research was designed to cover all the ten regions of the forest equally in order to have uniformity in the collection of the data. Distances from the forest boundary (DFB), site and road classes were the main factors (Figure 6). In every road class, there were twelve (12) plots that were at regular intervals giving a total of forty-eight (48) plots per site. This was repeated for each site and thus the total number of plots were 480 plots which measured 0.2 ha (circular plots). The final design was a randomized complete block with four replicates.

\subsubsection{Sampling Techniques and Data Collection}

This study was carried using the linear tape measure. The GPS, was used to map the plots of study while a "panga", was used for the clearing of the thickets for easier observation. Primary and secondary data involved the collection of information from already documented literature on the forest roads and published work, from the Internet, reports and journals. A sample of 96 Hectares was taken from different parts of the forest to represent the whole forest. Multistage sampling was used to identify the sampling units. Random sampling was employed to identify the road classes to be used in the study after which systematic sampling was employed to sample the plots from different parts of the selected road or path using the procedure below. The sampling was done in the whole forest in that in every site the study was started by a drive through or a walk along the boundary in order to document the amount of roads and paths that are available in a given area. One road class one was selected randomly. After selection of these roads, plots were established uniformly up to a distance of three kilometers inside the forest. The plots were established at an interval of $0.2 \mathrm{~km}$. Circular plots of 0.2 hectares were used in the study.

\subsubsection{Sampling Layout}

\begin{tabular}{|c|c|c|c|c|c|c|c|c|c|c|c|}
\hline $\begin{array}{l}0.2 \\
\mathrm{~km}\end{array}$ & $\begin{array}{l}0.4 \\
\text { km }\end{array}$ & $\begin{array}{l}0.6 \\
\mathrm{~km}\end{array}$ & $\begin{array}{l}0.8 \\
\text { km } \\
\end{array}$ & $\begin{array}{l}1.2 \\
\mathrm{~km}\end{array}$ & $\begin{array}{l}1.4 \\
\text { km }\end{array}$ & $\begin{array}{l}1.6 \\
\mathrm{~km}\end{array}$ & $\begin{array}{l}1.8 \\
\text { km } \\
\end{array}$ & $\begin{array}{l}2.2 \\
\mathrm{~km}\end{array}$ & $\begin{array}{l}2.4 \\
\mathrm{~km}\end{array}$ & $\begin{array}{l}2.6 \\
\mathrm{~km} \\
\end{array}$ & $\begin{array}{l}2.8 \\
\text { km }\end{array}$ \\
\hline
\end{tabular}

Figure 6. Plot distances from the boundary.

\subsubsection{Factors Assessed and Variables}

The following factors were the ones investigated:

a. DFB (DFB) of $1 \mathrm{KM}, 2 \mathrm{KM}$ and $3 \mathrm{KM}$.

b. Road classes: 20c, 40c, 50c and 70c. Where 20c was the poorest and $75 \mathrm{c}$ is the best road.

c. Different forest sites.

The number of number of stumps were studied in the field by counting the number of cut stumps in a particular plot aimed at showing the rate of illegal felling of trees in different regions of different road classes and to show the trend as one moves from the boundary to the inside of the forest and also to study variability in different areas of the forest. The number of traps would show the availability of animals in different parts of the forest apart from showing the number of traps in the different regions. This was designed to show the relationship of the illegal animal hunting in relation to the forest infrastructure. The number of herbal medicine collection was related to the number of incidences of root digging in the forest. These were counted and recorded in terms of quantities, while the number of stacks were counted as the number of stacked firewood, withes, poles, timber and logs in any particular location and road class. The number of paths was used as a variable in the study to show the parts of the forest which are mostly utilized by the people for any activity. This was to correlate number of paths as regards road classes, DFB and relative location of site. The number 
of debarked trees was studied as an illegal activity in the forest. This would also show the trend of this in the forest in relation to the forest road classes This was located in the field by looking for the debarked trees and recording these in terms of the quantity.

\subsubsection{Data Analysis}

The data collected and managed by Microsoft excel and subjected analysis of variance (ANOVA) using the Genstat 8.0 Software (2010) and the means separated by least significant difference at $\mathrm{p}<0.05$.

\section{Results and Discussions}

\subsection{Results}

The results of number of cut stumps found in various sites of Arabuko Sokoke Forest as affected by DFB and road classes are shown in Table 3. The Anova results revealed that all the sources of variation and their interactions were highly significant $(p<0.05)$. The incidences were highest in Sokoke $>$ Dida $>$ Kaembeni $>$ Jilore. The Nature reserve had on average very few cut stumps. It was evident that in poorer the road class and further the from the forest boundary, there were more stumps. This was irrespective of the site. The results of number of illegal animal traps found in various sites of Arabuko Sokoke Forest as affected by DFB and road classes are shown in Table 4. The Anova results revealed that all the sources of variation and their interactions were highly significant $(\mathrm{p}<0.05)$. No discernable pattern was found however as regards road class or DFB, however in general more numbers were detected in the $2 \mathrm{~km}$ DFB compared to 1 and $3 \mathrm{~km}$ DFB. DFB and Road class interactions was not significant at all although each was independently significant. The results of number of herbal collections found in various sites of Arabuko Sokoke Forest are shown in Table 5. Very few herbal collections were recorded with several sites recording none at all. However, of significance was that the nature reserve recorded a highest average. The many zero recordings could have influenced the final Anova and thus the results do not offer any particular conclusions. Table 6 shows that except for Malanga all the other sites had paths in all road classes and various distances from the boundary. The results of number of paths found in various sites of Arabuko Sokoke Forest as affected by DFB and road classes are shown in Table 7. The Anova results revealed that all the sources of variation and their interactions were highly significant $(\mathrm{p}<0.05)$. In general, all sites had paths running within the forest. This was more conspicuous in all sites except Malanga area. The highest number was recorded in Jilore followed by Matsangoni and Mwambani in that order. However, the DFB, Road class and site were highly significant in influencing the number of paths in the forest. More paths were recorded at $2 \mathrm{~km}$ DFB in all road classes in all sites. Debarking for various reasons are shown in Table 6. These were mainly concentrated in Dida, Kaembeni, Mwambani, and Sokoke. These results correlated well with herbal collections an indication that the debarking was probably for medicinal purposes.

Table 3. Number of cut stumps as affected by DFB, road class and relative location of sites.

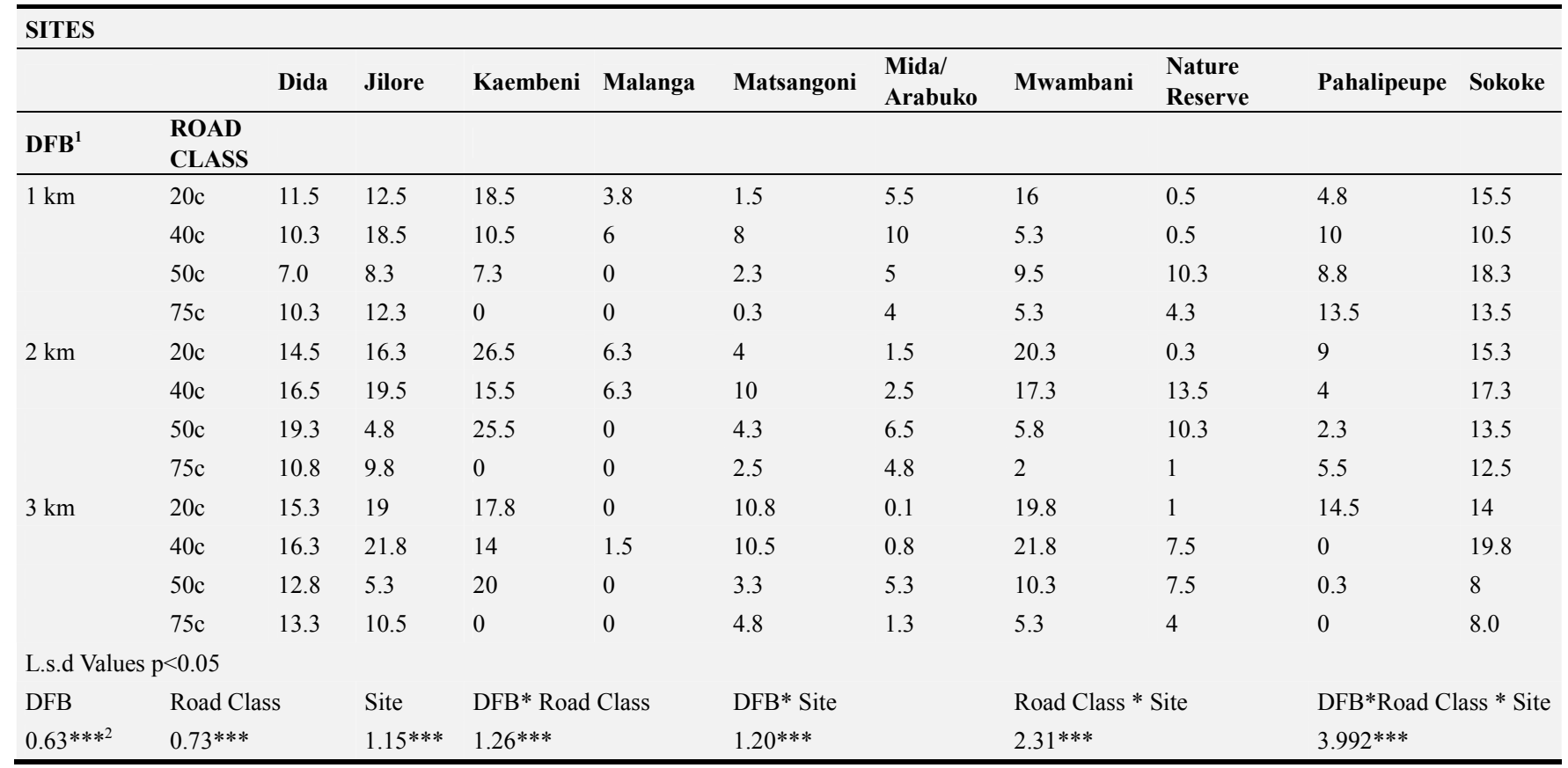

${ }^{1} \mathrm{DFB},{ }^{2 *}, * *, * * *$ means significant at $\mathrm{p}<0.05, \mathrm{p}<0.01$ and $\mathrm{p}<0.001$ respectively. 
Table 4. Number of animal traps as affected by DFB, road class and relative location sites.

\begin{tabular}{|c|c|c|c|c|c|c|c|c|c|c|c|}
\hline \multicolumn{12}{|l|}{ SITES } \\
\hline & & Dida & Jilore & Kaembeni & Malanga & Matsangoni & $\begin{array}{l}\text { Mida/ } \\
\text { Arabuko }\end{array}$ & Mwambani & $\begin{array}{l}\text { Nature } \\
\text { Reserve }\end{array}$ & Pahalipeupe & Sokoke \\
\hline DFB $^{1}$ & $\begin{array}{l}\text { ROAD } \\
\text { CLASS } \\
\end{array}$ & & & & & & & & & & \\
\hline \multirow[t]{4}{*}{$1 \mathrm{~km}$} & $20 c$ & 0 & 0.8 & 4.5 & 0 & 1.3 & 1 & 2 & 0 & 0 & 0 \\
\hline & $40 c$ & 0 & 0 & 1.8 & 0.75 & 0 & 1 & 0.8 & 0.5 & 0.5 & 1.3 \\
\hline & $50 \mathrm{c}$ & 0 & 0 & 1.3 & 0 & 0.3 & 0 & 0 & 0 & 0.5 & 0 \\
\hline & $75 c$ & 1.3 & 0 & 0 & 0 & 0 & 0.5 & 0 & 0 & 0.25 & 0.3 \\
\hline \multirow[t]{4}{*}{$2 \mathrm{~km}$} & $20 c$ & 2.0 & 0 & 0.5 & 1.5 & 1.3 & 0 & 4 & 0 & 3 & 0 \\
\hline & $40 c$ & 0.8 & 0 & 2.3 & 2.8 & 2.8 & 0 & 1 & 0 & 0 & 0.8 \\
\hline & $50 \mathrm{c}$ & 0 & 0 & 2.5 & 0 & - & 0 & 0.3 & 0 & 0.75 & 0.3 \\
\hline & $75 c$ & 0 & 0 & 0 & 0 & - & 0.3 & 0 & 0 & 0.5 & 0 \\
\hline \multirow[t]{3}{*}{$3 \mathrm{~km}$} & $20 c$ & 3 & 0 & 0.75 & 0.3 & 2.3 & 0.1 & 4 & 0.8 & 2.5 & 1.8 \\
\hline & $40 c$ & 0 & 0 & 1.5 & 0.5 & 2 & 0 & 0.8 & 0 & 0 & 1 \\
\hline & $75 c$ & 0.3 & 0 & 0 & 0 & 0 & 0 & 0 & 0 & 0 & \\
\hline \multicolumn{12}{|l|}{ L.s.d 0.05} \\
\hline DFB & Road Clas & & Site & DFB* Road & Class & DFB* Site & & Road Class * & Site & DFB*Road $\mathrm{Cl}$ & ss * Site \\
\hline $0.21 \mathrm{~ns}^{2}$ & $0.24 * * * 3$ & & $0.39 * * *$ & $0.42 \mathrm{~ns}$ & & $0.67 * *$ & & $0.77 * * *$ & & $1.43 * * *$ & \\
\hline
\end{tabular}

${ }^{1} \mathrm{DFB},{ }^{2 *}, * *, * * *$ means significant at $\mathrm{P}<0.05, \mathrm{p}<0.01$ and $\mathrm{p}<0.001$ respectively.

Table 5. Herbal collection as influenced by relative location of sites.

\begin{tabular}{ll}
\hline Site & Herbal Collections \\
\hline Dida & 0.063 \\
Jilore & 0.000 \\
Kaembeni & 0.104 \\
Malanga & 0.000 \\
Matsangoni & 0.021 \\
Mida/Arabuko & 0.001 \\
Mwambani & 0.063 \\
Nature Reserve & 0.208 \\
Pahalipeupe & 0.000 \\
Sokoke & 0.000 \\
L.s.d $(\mathrm{p}<0.05)$ & $0.093 * * 1$ \\
\hline
\end{tabular}

${ }^{1} \mathrm{DFB},{ }^{2} \mathrm{~ns}=$ not significant at $\mathrm{p}<0.05,{ }^{3 *}, * *, * * *$ means significant at $\mathrm{P}<0.05, \mathrm{p}<0.01$ and $\mathrm{p}<0.001$ respectively.

Table 6. Influence of forest roads, DFB and relative location of sites on the number of paths in the forest.

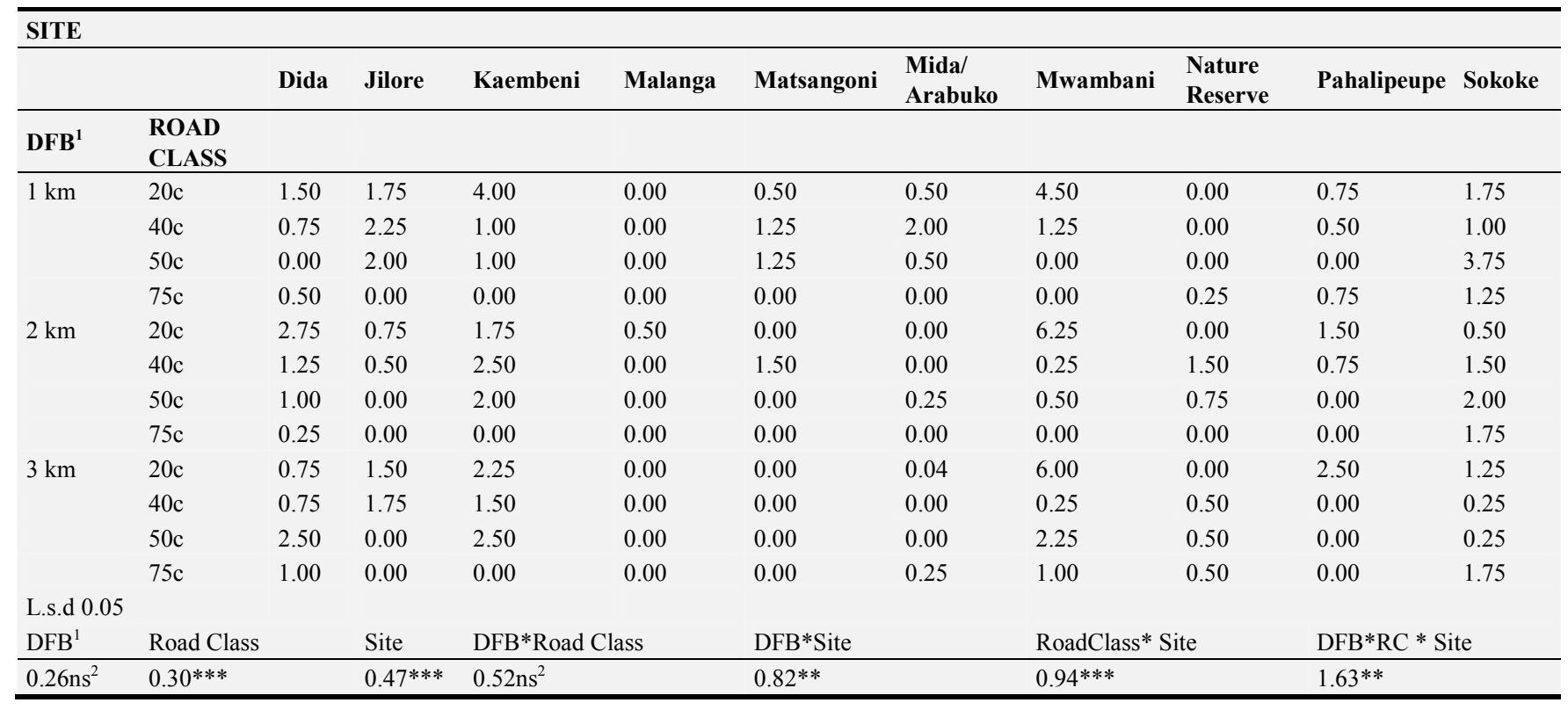

${ }^{1} \mathrm{DFB},{ }^{2} \mathrm{~ns}=$ not significant at $\mathrm{p}<0.05,{ }^{3 *}, * *, * * *$ means significant at $\mathrm{P}<0.05, \mathrm{p}<0.01$ and $\mathrm{p}<0.001$ respectively. 
Table 7. Number of paths as affected by DFB, road class and relative location of sites.

\begin{tabular}{|c|c|c|c|c|c|c|c|c|c|c|c|}
\hline \multicolumn{12}{|l|}{ SITE } \\
\hline & & Dida & Jilore & Kaembeni & Malanga & Matsangoni & $\begin{array}{l}\text { Mida/ } \\
\text { Arabuko }\end{array}$ & Mwambani & $\begin{array}{l}\text { Nature } \\
\text { Reserve }\end{array}$ & Pahalipeupe & Sokoke \\
\hline $\mathrm{DFB}^{1}$ & $\begin{array}{l}\text { ROAD } \\
\text { CLASS }\end{array}$ & & & & & & & & & & \\
\hline \multirow[t]{3}{*}{$1 \mathrm{~km}$} & $20 c$ & 2 & 2.5 & 3 & 0.3 & 3.6 & 2 & 3.8 & 1.6 & 1.3 & 1.8 \\
\hline & $40 c$ & 1.5 & 3 & 1.5 & 1.8 & 2.3 & 3 & 1.6 & 3 & 2 & 1.3 \\
\hline & $50 \mathrm{c}$ & 1.3 & 2.8 & 1.5 & 0 & 1.8 & 3 & 2.8 & 2.5 & 1.5 & 3.5 \\
\hline \multirow[t]{4}{*}{$2 \mathrm{~km}$} & $20 c$ & 1.8 & 4.5 & 1.5 & 1.8 & 1.8 & 1 & 4.8 & 2.5 & 1.5 & 2.3 \\
\hline & $40 c$ & 2 & 3.8 & 1.5 & 1.5 & 2.5 & 1 & 3 & 1.8 & 1.8 & 2 \\
\hline & $50 \mathrm{c}$ & 1 & 2.8 & 2.5 & 0 & 1.8 & 3.3 & 2.5 & 2.5 & 1.3 & 3 \\
\hline & $75 c$ & 1.5 & 2.3 & 0 & 0 & 1.8 & 2 & 1 & 1.5 & 1.5 & 0 \\
\hline \multirow[t]{3}{*}{$3 \mathrm{~km}$} & $20 c$ & 2.8 & 6.8 & 2.3 & 0 & 4.8 & 0 & 4.5 & 2 & 1.8 & 2 \\
\hline & $40 c$ & 1.8 & 3.8 & 1.8 & 1.3 & 3.5 & 1.5 & 5 & 2.8 & 0 & 2.3 \\
\hline & $50 \mathrm{c}$ & 1.8 & 1.3 & 1.8 & 0 & 2 & 1.8 & 2.3 & 2 & 0 & 1.3 \\
\hline DFB & Road Class & Site & & DFB*Road C & & DFB*Site & & Road C* Site & & DFB*RC $*$ Site & \\
\hline $0.22 \mathrm{~ns}^{2}$ & $0.25 * * * 3$ & $0.40 * * *$ & & $0.44 * * *$ & & $0.70 * * *$ & & $0.80 * * *$ & & $1.38 * * *$ & \\
\hline
\end{tabular}

${ }^{1} \mathrm{DFB},{ }^{2} \mathrm{~ns}=$ not significant at $\mathrm{p}<0.05,{ }^{3 *}, * *, * * *$ means significant at $\mathrm{P}<0.05, \mathrm{p}<0.01$ and $\mathrm{p}<0.001$ respectively.

Table 8. Number of debarking incidences as affected by DFB, road class and relative location of sites.

\begin{tabular}{|c|c|c|c|c|c|c|c|c|c|c|c|}
\hline \multicolumn{12}{|l|}{ SITE } \\
\hline & & Dida & Jilore & Kaembeni & Malanga & Matsangoni & $\begin{array}{l}\text { Mida/ } \\
\text { Arabuko }\end{array}$ & Mwambani & $\begin{array}{l}\text { Nature } \\
\text { Reserve }\end{array}$ & Pahalipeupe & Sokoke \\
\hline $\mathrm{DFB}^{1}$ & $\begin{array}{l}\text { ROAD } \\
\text { CLASS }\end{array}$ & & & & & & & & & & \\
\hline \multirow[t]{4}{*}{$1 \mathrm{~km}$} & $20 c$ & 0.8 & 0 & 5.3 & 0.3 & 0 & 0 & 4.8 & 0 & 0.3 & 0.8 \\
\hline & $40 c$ & 0.5 & 0 & 0.3 & 0.5 & 0 & 0 & 1 & 0.5 & 0.5 & 0.3 \\
\hline & $50 \mathrm{c}$ & 0 & 0 & 0.5 & 0 & 0 & 0 & 0.5 & 0 & 0 & 0.8 \\
\hline & $75 c$ & 0.8 & 0 & 0 & 0 & 0 & 0 & 0 & 0 & 0 & 0.5 \\
\hline \multirow[t]{4}{*}{$2 \mathrm{~km}$} & $20 c$ & 0.8 & 0 & 1 & 0.3 & 0 & 0 & 5 & 0 & 2.3 & 0.5 \\
\hline & $40 c$ & 1.3 & 0 & 2 & 0.3 & 0 & 0 & 1.3 & 0 & 0.5 & 1.5 \\
\hline & $50 \mathrm{c}$ & 0 & 0 & 1.8 & 0 & 0 & 0 & 0.3 & 0 & 0 & 0.8 \\
\hline & $75 c$ & 0.3 & 0 & 0 & 0 & 0 & 0.5 & 0 & 0 & 0 & 0 \\
\hline \multirow[t]{4}{*}{$3 \mathrm{~km}$} & $20 c$ & 1.5 & 0 & 1.3 & 0 & 0 & 0 . & 5.3 & 0 & 2.5 & 0.5 \\
\hline & $40 c$ & 0.8 & 0 & 1.3 & 0 & 0.5 & 0 & 1.8 & 0.3 & 0 & 0.8 \\
\hline & $50 c$ & 0.3 & 0 & 1.3 & 0 & 0 & 0 & 1 & 0.5 & 0 & 0 \\
\hline & $75 c$ & 0.3 & 0 & 0 & 0 & 0 & 0 & 0.3 & 0 & 0 & 0.3 \\
\hline \multicolumn{12}{|c|}{ L.s.d 0.05} \\
\hline DFB & Road Class & Site & & DFB*Road & ass & DFB*Site & & Road Class* & ite & $\mathrm{DFB} * \mathrm{RC} * \mathrm{Si}$ & \\
\hline $0.18 \mathrm{~ns}^{2}$ & $0.20 * * * 3$ & $0.16 * * *$ & & $0.18 \mathrm{~ns}$ & & $0.28 \mathrm{~ns}$ & & $0.33 * * *$ & & $0.57 * * *$ & \\
\hline
\end{tabular}

${ }^{1} \mathrm{DFB},{ }^{2} \mathrm{~ns}=$ not significant at $\mathrm{p}<0.05,{ }^{3 *}, * *, * * *$ means significant at $\mathrm{P}<0.05, \mathrm{p}<0.01$ and $\mathrm{p}<0.001$ respectively.

\subsection{Discussion}

Referring to the analysis of variance table (Table 3), all the factors that stumps were subjected to and their interactions were highly significant $(p<0.001)$. All the factors are important to put in consideration when one is aiming to control poaching of the trees. The poorer road classes have more stumps found in the forest regions near them as compared to the better road classes. DFB is also a factor that is vital in the influencing the number of stumps in a particular region of the forest. Different sites have different values of average number of stumps. This can be attributed to the fact that different sites have different tree requirements by the local people, different tree species are found in different regions and also different sites have different rates of patrolling by the forest protection unit. The past experience shows that in Kaembeni and Malanga areas the wood carvers are the common poachers and the species that are targeted mostly are the Muhuhu (Brachyleana huillensis). Other timber species are mostly in this area that are also poached in these areas because of land poles and timber. These areas that have evidence of the wood-carving in the forest. The results show that Sokoke, Jilore, Dida, Kaembeni, Mwambani are areas with the highest readings and the areas with the lowest readings include Mida \& Arabuko, Malanga, Matsangoni, Pahali peupe, Nature reserve. Areas like Sokoke have got a very high reading on the number of cut stumps. These stumps include the stumps of poles and wood for timber purposes. The nearness to Kilifi town is also a contributing factor to the amount of the illegal cut stumps in this region especially from Dida and Mwambani These regions are far away from the main forest station and those that are near like Sokoke and Dida have very few Forest guards or rangers who are 
used in the forest protection. One forest guard is assigned at least 1816 hectares to patrol which is a very large area for one to cover on foot. If one was to arrest any offender one has to be well armed with the proper equipment in order to carry out the duties effectively. The further one is from the boundary the higher the number of stumps found in the forest. This is well shown in the sites like Dida, Jilore, and Kaembeni areas. In Dida, the average number of stumps at $1 \mathrm{~km}, 2 \mathrm{~km}$, and $3 \mathrm{~km}$ is $11.5,14.5$, and 15.3 respectively, while in Jilore, it is $12.5,16.3$ and 17.8 respectively. Other areas are as shown in the Table 1. Even if the overall analysis shows that the average number of stumps increases from the boundary as you go inside to the third kilometer, this is not always the case as it is the case in some of the areas like nature reserve. Generally, this analysis shows that illegal cutting of trees is very much influenced by the presence or the absence of the proper roads in the forest. The combination of the three factors is highly significant. Some historical factors also contribute to the higher readings recorded in Kaembeni and Mwambani. For example, the locals at Kaembeni since the early 1930s knew about woodcarving and this has progressed from generation to generation. The outsiders currently involved came to look for raw materials for the established Mombasa market under licensing from KFS. Despite the ban of 1983 the activities continued albeit illegally to generate income to provide for their families, since no other alternatives were given to them as a source of livelihood. Kaembeni is currently managed from Dida and Kaembeni outposts manned by at least 2 people with no communication equipment. The distance between them is approximately $10 \mathrm{~km}$ thus making patrolling difficult. The other factor is that wood-carvers (illegal operators) are adjacent to the forest while the outposts are situated far away. This gives the illegal operators a lot of time to carry out their illicit activities. The only road that passes through the area is the forest boundary road. The extraction and access roads have since closed since the banning of timber extraction. This makes any support e.g. vehicles or more guards from the out stations to lees effective. The illegal operators are normally on foot or use bicycles. As for Mwambani, there is no outpost at all and is administered by personnel who stay at least $5 \mathrm{~km}$ away from the forest boundary. Mwambani area is also near Kilifi, which is a source of market for timber especially, Afzelia and Brachystegia. The roads are also inaccessible except the forest boundary road. As for Traps (Table 3) the factors that are highly significant include the road class and the site. The DFB is not significant and this actually shows that the illegal hunters can set their traps anywhere in the forest irrespective of the DFB. Road class is another factor, which is actually highly significant as far as trapping is concerned. From the results, it is evident that the poorer the road class the more the traps found. This shows that the road class is very much a factor in the influence of the trapping also. Site is another factor that is of importance and of influence as far as trapping of the animals in the forest is concerned. Different sites have different readings just as in the stumps. Animal trapping is influenced by the different vegetation types in the forest, different population patterns of animals, and the different feeding habits of people living around different regions of the forest. The combination of the three factors i.e. site, DFB and $\mathrm{RC}$ is highly significant. Referring to the history of the Arabuko Sokoke forest it is evident that trapping of the wild animals is not a new practice. This practice started long time ago by the Sanya people who are the original people of the area surrounding the forest. They usually hunt the small animals for food. The traps recorded in the forest were those for catching small animals. Hunting is an activity that may take time to cease because the forest surrounding communities are depending on the forest small animals for the proteins. [14] reported that majority of the forest adjacent communities depended on the forest for $90 \%$ of their protein supply. However, this can be controlled by advising the local communities to look for alternative ways to get proteins from other sources other than the forest animals. From Table 3 there is no significant difference among different road classes on the influencing the herbal collection. The DFB is not a significant factor as far as the herbal collection is concerned. The site factor is the only one factor that is seen to be having a significant influence on the herbal collection. This is may be because of the fact that these herbal collectors are found in specific areas and they are not all over the forest. This is one of the variables that had the lowest readings in the study. This is not a frequent illegal activity in this forest. The low readings could be attributed to the specialized nature of the work. Herbalists generally do their work with a lot of secrecy. Table 4 shows the influence of roads, DFB and sites on the number of paths. It is evident that apart from the DFB all the other factors were highly significant influencing the number of paths in the forest. Road class as a factor influences the path availability in the forest as shown in the below. The better the road class the lower the availability of paths in a particular region. DFB becomes a significant factor when it is combined with other factors. For example:

Table 9. Relationship between road class $(R C)$ and No. of Paths.

\begin{tabular}{lllll}
\hline Road Class (RC) & 20c & 40c & 50c & 75c \\
\hline No. of paths & 2.385 & 2.158 & 1.833 & 1.333 \\
\hline
\end{tabular}

The Classes beyond 40c have got fewer number of paths. This can be attributed to the fact that the regions with better RCs people do not need to make their path to follow but in the areas with no road people have to pass through the forest through a path. The other factor that can be causing the number of paths to reduce in the areas near the roads is that not many illegal activities are being carried out near the major roads. As a result, the users of this section of the forest are also fewer as compared to the regions with no forest roads. As shown by the means above it is evident that there is a lot of utilization of the forest in the areas that have no proper road network passing through. The people around the forest use these paths for many purposes. Other places that have higher number of illegal activities have also a higher number of paths. Results of the number of stacks revealed that RC and the DFB 
are most important factors as far as the stacks collection are concerned. These are factors that mostly affect this illegal activity. These two factors are the most important factors in the influencing the collection of the firewood and of the other form of stacks. From the results presented in Table 6 it is evident that the most important factors in this influencing debarking are the site and RC. The DFB is not an important factor as far as debarking of the trees in the forest is concerned. However, the combination of the three factors is very significant and therefore the conclusion is that they all do have an influence on this illegal activity.

\section{Conclusions}

From the discussion above it is very evident that there is a varying effect of the forest roads, paths and tracks on different illegal activities. Illegal cutting of the trees has been positively influenced by the forest roads. This is well illustrated by the results. It shows very clearly that the poorer the road class the higher the number of tree stumps found in the forest.

This leads to the following deductions from the study:

a. The poachers operate away from the major roads to avoid the confrontations with the rangers and the forest guards on patrol.

b. The poachers do not require the roads in their harvesting activities in order to carry out their activities.

c. It is also an indication that the passage of vehicles through the forest irrespective of whether patrolling or any other activity has a very significant effect on the activities taking place in the forest. The low values of the illegal cutting of trees near the major roads and higher values near the paths have showed this.

d. It is also indicated that the far inside one is, in the forest the more the illegal cutting of the trees one observes, hence the DFB becomes a very important factor in the control of the illegal activities

e. Different sites have their different rates of poaching in the forest and this can be attributed to factors specific to each site. These factors include the; availability of raw materials, availability of poachers etc

f. The forest guards are few in their stations and are also ill equipped and this makes it difficult for any arrest to be carried out in the forest. This also becomes a problem when one is arrested and has to be transported to a far distance.

g. The fact that the forest guards are ill equipped can also be a reason for the forest guards and patrol men not to walk far away.

h. Finally, the combination of the three factors is very important in the control of the illegal cutting of the trees and other illegal activities in the forest.

i. The discussion above leads to the following deductions:

j. Forest roads affect very much the site of illegal animal hunting. The further one is from the major roads the higher the frequency of trapping of the animals.

k. This also suggests that the availability of animals decrease as better road classes increase in the forest. This is because of the animals keeping away from the major roads as they are usually busy.

1. On the other hand, the DFB does not affect the presence of the animal traps.

\section{Recommendations}

It is evident that the forest roads have a very high influence on the illegal activities in the Arabuko Sokoke forest and this leads to a recommendation that some of the abandoned roads must be cleared and maintained for the better patrolling of the forest. This should involve the clearing of the forest roads which mostly will have multiple use in the forest in order to try and counter balance the cost of maintaining a lot of roads in the forest. Forest roads also affect the biodiversity of the forest as a whole and hence the clearing of the forest should be done in a way not to affect the biodiversity. In order to choose the best areas to have the roads cleared there should be a well detailed survey of all the paths and the roads in the Arabuko Sokoke forest in order to document the statistics of the available paths and roads that exist in the forest. This will guide the forest managers in the decision making on which roads and paths should be cleared and as the study shows, different areas have different resource use pattern. This will display the areas with an immediate need for a road and areas that do not have strict needs for a road.

a. The forest guards should be properly equipped for the exercise, and proper incentives put in place to avoid low morale in the working environment.

b. A Permanent group should be put in place for the spot checks and to set ambush in different areas at different times in order to control poaching especially for the areas with very high figures of illegal activities like Kaembeni and the Mwambani areas among others.

c. The out posts already in place should be strengthened and proper communication be installed to affect the control of poaching.

\section{Acknowledgements}

The authors would like to extend their gratitude to the European Commission who funded the above study through BirdLife International, Arabuko Sokoke Forest Management and Conservation Project. The authors appreciate the assistance of Mr. F. M. Mang'ee (Forester, Gede Forest Station) and Mr. C. Mwakworo (Forester Sokoke Forest Station) during the fieldwork and contributing to the discussions. The authors are also grateful to the Forest Department Forest Guards and Kenya Wildlife Service Rangers who helped in various parts of the forest.

\section{References}

[1] Potocnik, I. (1993). Economic aspects of forest roads' maintenance. Zbornik gozdarstava in lesarstava (41): 155-171. 
[2] Potocnik, I. (1996). The multiple use of forest roads as a criterion for their categorization. Dissertation thesis. Biotechnical Faculty, Ljubljana, XV +241 pp.

[3] Gjedtjernet, A. M. F. (1994). Forest operations and environmental protection. Proceedings of Int. NEFU/IUFRO/FAO/FEI Seminar. Harbin.

[4] Suchomel, J. and Lukac, D. (1995). Modelling and optimizing of harvesting methods - Multicriterional analysis. XX IUFRO Congress, S3.06 Meeting, Tampere.

[5] Potocnik Igor, Takuyuki Yohioka, Yoshinori Miyamoto, Hideo Igarashi and Hideo Asaki (2005). Maintenance of forest road network by natural forest management in Tokyo University Forest in Hokkaido. Croatian Journal of Forest Engineering 26 (2005) 2.

[6] Aruga, K., Nakamura, K., Sakai., Kobayashi, H., Watanabe, S. (2001). The role of logging roads in water and soil conservation. Thinnings: A valuable forest management tool. IUFRO Unit 3.09.00. International Conference, Quebec, Canada.

[7] Mwendwa, K. A. (2000). Proposed zonation of ArabukoSokoke Forest for the purposes of strategic management planning. Unpublished ASFMCP Discussion paper.

[8] Kelsey, M. J. and Langton, T. E. S. (1984). The Conservation of Arabuko Sokoke Forest, Kenya. International Council for Birds Preservation and University of East Anglia. ICBP study report no. 4 Cambridge: International Council for Birds Preservation.

[9] Robertson, S. A and Luke, W. R. Q. (1993). Kenya Coastal Forests. The report of the NMK/WWF coast forest survey. WWF project 3256: Kenya, Coast Forest Status, Conservation and Management. Nairobi, Kenya: World Wide Fund For Nature.

[10] Moomaw, J. C. (1960). A Study of The Plant Ecology of the Coastal Region of Kenya, East Africa. Nairobi, Kenya: Government Printers.
[11] Blackett, H. L (1994). Forest Inventory Report Number 2: Arabuko Sokoke. Nairobi, Kenya: Kenya indigenous Forest Conservation Project.

[12] Borota, J. (1991). Tropical Forest: Some African and Asian case studies of composition and structure. Developments in Agriculture and Managed Forest Ecology. Amsterdam, The Netherlands: Elsevier Science.

[13] Chebures, B. J. and Fanshawe, J. H. (1990). Arabuko Sokoke Forest Reserve as a National Park. A Preliminary KWS Report. Unpublished manuscript. Wildlife Planning Unit, Kenya Wildlife Service.

[14] Forbes-Watson, A. (1971). Cited in Ripley, S. D. \& Bond, G. M. Systematic notes on a collection of birds of Kenya. Smithsonian contributions to Zoology.

[15] Mogaka, H. R. (1991). Local Utilization of Arabuko-Sokoke Forest Reserve. Department of Forestry, Nairobi: Kenya Indigenous Forest Conservation Project, Overseas Development Administration.

[16] FitzGibbon, C. D. and Fanshawe, J. H. (1992). The influence of subsistence Hunting on the Fauna of Arabuko Sokoke forest, Kenya. A preliminary report on a joint study by the ICBP/NMK Arabuko Sokoke Forest Project and Kenya Indigenous Forest Conservation Project.

[17] FitzGibbon, C. D., Mogaka, H. and Fanshawe, J. H. (1995). Subsistence hunting in Arabuko Sokoke Forest, Kenya and its effects on populations of mammalian prey. Conservation biology 9: 1116-1126.

[18] FitzGibbon, C. D. (1994). The distribution and abundance of the golden-rumped elephant-shrew Rhynchocyon chrysopygus in Kenya Coastal forests. Biological Conservation 67: 153160. 